\title{
Neuraminidase and $N$-Acetylneuraminate Pyruvate-Lyase of Pasteurella multocida
}

\author{
By R. DRZENIEK*, W. SCHARMANN AND ERIKA BALKE \\ Institute für Virologie, für Bakteriologie und Immunologie, und für Hygiene und \\ Infektionskrankheiten der Tiere, Universität Giessen, West Germany
}

(Accepted for publication I May 1972)

\begin{abstract}
SUMMARY
Neuraminidase was found in nearly all strains of Pasteurella multocida, in some strains of $P$. haemolytica, but not in $P$. pseudotuberculosis. The enzyme of $P$. multocida is bound to the bacterial cell. It is inducible by $N$-acetyl-D-mannosamine and by free and bound sialic acid. After solubilization it has a molecular weight of about 250000 , a pH optimum $=6 \cdot 0$, and a Michaelis constant $K_{m}=2 \times 10^{-4} \mathrm{M}$ when $3^{\prime}$-sialyllactose is used as substrate.

$\mathrm{N}$-acetylneuraminate pyruvate-lyase activity present in Pasteurella multocida is higher in the cell-free culture medium than in the bacterium.

It is suggested that the stimulating effect of blood sera on the production of neuraminidase by Pasteurella multocida is due to the delayed release of the inducer $N$-acetyl-D-mannosamine.
\end{abstract}

\section{INTRODUCTION}

The enzyme neuraminidase ( $N$-acetylneuraminate glycohydrolase, EC. 3.2.1 . I 8 ) is present in differential bacterial strains, but all belonging to the order of the Pseudomonadales and Eubacteriales (Drzeniek, I972). In a short communication we have reported the existence of neuraminidase in Pasteurella multocida and P. haemolytica (Scharmann, Drzeniek \& Blobel, I970). Independently, Tsolov \& Karadzhov (1969) and Müller (I97I) described the existence of neuraminidase in P. multocida. Earlier, Laurell (1959) had found neuraminidase in $P$. pseudotuberculosis.

Neuraminidase of Pasteurella multocida exerts a characteristic action on human transferrins: it splits a homogeneous transferrin band from humans, type CC, into five bands when examined by polyacrylamide gel electrophoresis (Scharmann, Brückler \& Blobel, I97I). Since this enzyme is bound to the bacterial cell which contains also other enzymatic activities, among them $\mathrm{N}$-acetylneuraminate pyruvate-lyase (EC. $4 \cdot \mathrm{I} \cdot 3 \cdot 3$ ) (Scharmann et al. I970; Müller, I97I), it was necessary to release neuraminidase from the cell and to purify it.

This paper reports differences in the induction of neuraminidase by $N$-acetyl-D-mannosamine and different blood sera, the solubilization, partial purification and characterization of the enzyme, and gives further evidence for $N$-acetylneuraminate pyruvate-lyase activity in Pasteurella multocida.

\section{METHODS}

Bacteria. One hundred and four strains of Pasteurella multocida were investigated; 23 strains of type A, five of type B, one of type C, I4 of type D and four of type E. The remaining strains were not typed. We thank Dr P. Perreau, Maisons-Alfort, France, Dr J. E. Smith, London, and Dr Fujita, Tokyo, for supplying us with these strains. The types corresponded to Carter's classification (Carter, 1967). Five strains of $P$. haemolytica

* Present address: Heinrich-Pette-Institut, 2 Hamburg 20, Martinistrasse 52, West Germany. 
(Collection of Animal Pathogenic Micro-organisms, Brno, Czechoslovakia) and six strains of P. pseudotuberculosis (Collection of the Institute of Bacteriology, Giessen, Germany) were also tested for neuraminidase activity.

Bacterial count. Viable count determinations were made by plating (Collins \& Lyne, 1970). The extinction of the culture was determined at $625 \mathrm{~nm}$ in a Bausch \& Lomb spectrophotometer (Spectronic 20).

Media. Brain heart infusion (Difco) with $5 \%$ rabbit serum was used in experiments in which the occurrence of neuraminidase activity in Pasteurella strains was examined. In order to produce larger amounts of neuraminidase, $\mathrm{I} \%(\mathrm{w} / \mathrm{v})$ Casamino acids (Difco) and $10 \%(\mathrm{v} / \mathrm{v})$ sheep serum added to the brain heart infusion were used.

As basal medium for the induction tests I $\%(\mathrm{v} / \mathrm{v})$ yeast diffusate was used supplemented with $\mathrm{I} \%(\mathrm{w} / \mathrm{v})$ Casamino acids and $0.5 \%(\mathrm{w} / \mathrm{v}) \mathrm{Na}_{2} \mathrm{HPO}_{4}, \mathrm{I}_{2} \mathrm{H}_{2} \mathrm{O}$. Yeast diffusate was obtained by dialysing $\mathrm{I} g$ of yeast extract (Oxoid) against $\mathrm{I} 00 \mathrm{ml}$ of distilled water (Scharmann \& Blobel, 1968). $N$-acetyl-D-mannosamine was obtained from Sigma, St. Louis, Missouri, U.S.A., and $N$-acetylneuraminic acid (NANA) from Calbiochem, Los Angeles, California, U.S.A. Bovine sialyllactose together with $\mathrm{N}$-acetylneuraminosyl- $(\alpha, 2 \rightarrow 3)$ D-lactose (alternative name: 3 -sialyllactose) and fetuin were prepared as described previously (Drzeniek, 1970).

Growth of bacteria. Samples of $100 \mathrm{ml}$ of the above-mentioned enriched medium were autoclaved in 1 Erlenmeyer flasks and inoculated with $5 \times 10^{8}$ bacteria from a culture $6 \mathrm{~h}$ old. They were incubated for $66 \mathrm{~h}$ at $37^{\circ} \mathrm{C}$ in a rotating shaker at $100 \mathrm{rev} . / \mathrm{min}$. A final population of $8 \times 10^{9} \mathrm{cells} / \mathrm{ml}$ was obtained when the medium was enriched with sheep serum. The bacteria were then separated from the culture fluid by centrifugation $(27300 \mathrm{~g}$, $20 \mathrm{~min}$ ) and washed once with $0 . \mathrm{I} \mathrm{M}$-phosphate buffer, $\mathrm{pH} \mathrm{6.5}$. The cells were suspended in the same buffer (one fifth of the volume of the culture fluid).

Solubilization of neuraminidase. To solubilize the cell-bound neuraminidase from Pasteurella multocida, washed bacteria were ultrasonicated at a frequency of $20 \mathrm{kc} / \mathrm{s}$ with an instrument of $125 \mathrm{~W}$ capacity (Branson Sonifier S I25, Branson Instruments Inc., Danbury, Connecticut, U.S.A.). Treatment periods did not exceed $15 \mathrm{~s}$ with intervals between treatments of $\mathrm{I}$ to $2 \mathrm{~min}$, in order to avoid heat denaturation of the enzyme. In addition, the treated tube was kept at $-10{ }^{\circ} \mathrm{C}$. After 20 sonications the sample was centrifuged (3 $\mathrm{I} 000 \mathrm{~g}$, $20 \mathrm{~min}$ ), the supernatant collected, and the sediment resuspended in the same volume of 0.I M-phosphate buffer, $\mathrm{pH} 6.5$. The sonication procedure was repeated twice to disintegrate all bacteria.

For the $\mathrm{NaCl}$ extraction, the phosphate-buffered bacterial suspension was made $0.4 \mathrm{M}$ with respect to sodium chloride. After $15 \mathrm{~min}$ of incubation at $37^{\circ} \mathrm{C}$, the cells were centrifuged for $20 \mathrm{~min}$ at $31000 \mathrm{~g}$ and the supernatant was collected. The cells were re-extracted twice to obtain a pool of three extracts.

Determination of virulence. White mice ( $\mathrm{I} 6$ to $20 \mathrm{~g}$ ) were infected with increasing dilutions of a $\mathrm{I} 6 \mathrm{~h}$ culture of the appropriate Pasteurella multocida strain. The dilutions were made with brain heart infusion broth. In 'high virulence' strains 50 to 500 bacteria were lethal within $48 \mathrm{~h}$, whereas in 'low virulence' strains $5 \times 10^{6}$ to $5 \times 10^{9}$ bacteria were necessary to obtain the same effect.

Enzyme assays. Determination of neuraminidase activity was carried out as described in detail elsewhere (Drzeniek, Seto \& Rott, 1966; Drzeniek, 1970). Bacteria or extracts there of were incubated at $37{ }^{\circ} \mathrm{C}$ with $100 \mu \mathrm{g}$ of bovine sialyllactose (containing about $80 \%$ of $3^{\prime}$-sialyllactose) or with pure $3^{\prime}$-sialyllactose $(N$-acetyl $(\alpha, 2 \rightarrow 3)$-D-lactose $)$ in O-I M-phosphate buffer, $\mathrm{pH} 6.0$, in $0.5 \mathrm{ml}$ final volume. $N$-acetylneuraminic acid liberated from the substrate 
Table r. Neuraminidase activity in the genus Pasteurella

Cell-bound neuraminidase activity was determined in washed bacteria in 0.1 M-phosphate buffer, $\mathrm{pH} 6 \cdot 0$, by measuring the hydrolysis of bovine sialyllactose to free $N$-acetylneuraminic acid.

$\begin{array}{ccccc}\text { Species } & \text { Type } & \begin{array}{c}\text { Number of } \\ \text { strains } \\ \text { tested }\end{array} & \text { Detected } & \text { Not detected } \\ \text { Pasteurella multocida } & \text { A } & 23 & 23 & 0 \\ & \text { B } & 5 & 5 & 0 \\ & \text { C } & \text { I } & \text { I } & 0 \\ & \text { D } & \text { I } & 4 & \text { Neuraminidase } \\ \text { E. haemolytica } & \text { Entyped } & 57 & 55 & 0 \\ \text { P.pseudotuberculosis } & \text { Untyped } & 5 & 3 & 2 \\ & \text { Untyped } & 6 & 0 & 6\end{array}$

after 15 min of incubation was measured according to Aminoff's thiobarbiturate method (Aminoff, I961). The examined sample was properly diluted to obtain a straight line dependence between the amount of liberated $N$-acetylneuraminic acid and enzyme concentration: I $5 \mu \mathrm{g}$ of $\mathrm{N}$-acetylneuraminic acid liberated in $0.5 \mathrm{ml}$ of the test volume was the upper limit in our test procedure. The dependence of enzymatic cleavage of the substrate upon time and enzyme concentration has been described by us (Scharmann et al. 1970). In gel filtration experiments neuraminidase activity of the diluted fractions was determined using fetuin as substrate. The separated fractions were incubated for $15 \mathrm{~min}$ at $37^{\circ} \mathrm{C}$ in $0 . \mathrm{I} \mathrm{M}$ acetate buffer, $\mathrm{pH} 6.0$, with $\mathrm{I} \cdot 5 \mathrm{mg}$ fetuin in a final volume of $0.5 \mathrm{ml}$. Free sialic acid was measured according to Aminoff's method and expressed as $N$-acetylneuraminic acid.

$N$-acetylneuraminate pyruvate-lyase $(E C .4 . \mathrm{I} \cdot 3 \cdot 3)$ activity was determined by measuring the decrease of $N$-acetylneuraminic acid. Ten $\mu \mathrm{g}$ of $N$-acetylneuraminic acid in $0.3 \mathrm{ml}$ of $0.05 \mathrm{M}$-acetate buffer, $\mathrm{pH} 5.5$, and $0.2 \mathrm{ml}$ of the enzyme solution were incubated at $37^{\circ} \mathrm{C}$ for $15 \mathrm{~min}$. The reaction was stopped by the addition of sodium periodate, as generally used in the Aminoff procedure, and the remaining $N$-acetylneuraminic acid was measured.

Chromatography. Separation of $N$-acetylneuraminic acid and of $N$-acetyl-D-mannosamine was performed by descending chromatography on Schleicher \& Schüll [(3345), Dassel, Federal Republic of Germany] paper, 2043b, in butylacetate:acetic acid:water (3:2:I). Paper chromatograms were stained after $\mathrm{I} 6 \mathrm{~h}$ using the direct Ehrlich reaction for the visualization of $N$-acetylneuraminic acid (Gottschalk, I960) or the Morgan-Elson reaction for detection of $N$-acetyl-D-mannosamine (Horton, I969).

\section{RESULTS}

Evidence of neuraminidase in Pasteurella. Preliminary experiments with Pasteurella multocida showed that this species contains neuraminidase (Scharmann et al. 1970). Using a medium consisting of brain heart infusion and $5 \%$ rabbit serum, we were able to determine a maximum of neuraminidase activity of $P$. multocida strain A-43 after 60 to 70 h growth at $37^{\circ} \mathrm{C}$. Between $90 \%$ and $95 \%$ of the enzyme activity was bound to the cells; only 5 to $10 \%$ of the neuraminidase activity could be found in the cell-free supernatant. Therefore, I03 different $P$. multocida strains were examined for their content of cell-bound neuraminidase under the conditions for maximal enzyme activity given above. The highest neuraminidase activity was observed in the serological groups $\mathrm{A}$ and $\mathrm{D}$ as well as in some untyped strains. The strains of the serological group B showed only slight enzyme activity. Additionally, a 


\section{Table 2. Effect of different sera on the synthesis of neuraminidase by Pasteurella multocida}

Pasteurella multocida, strain A-43, was grown in brain heart infusion (Difco) supplemented with I $\%$ Casamino acids (Difco) in the absence and presence of $10 \%$ of human and of different animal sera. After $66 \mathrm{~h}$ of incubation at $37^{\circ} \mathrm{C}$, the amount of viable cells was counted by plating. Neuraminidase activity of the cells was determined as described in Methods. The amount of $N$-acetylneuraminic acid (NANA) liberated within $15 \mathrm{~min}$ in a test volume of $0.5 \mathrm{ml}$ by the appropriate dilution of the bacterial cells was converted into the amount of NANA which in our test procedure would be liberated by $\mathrm{I} \mathrm{ml}$ of the cells.

\section{Medium}

No serum

Bovine serum

Horse serum

Human serum

Rabbit serum

Swine serum

Sheep serum

Pasteurella multocida
cells $/ \mathrm{ml}$
$8 \times 10^{8}$
$\mathrm{I} \times 10^{9}$
$\mathrm{I} \cdot 2 \times 10^{9}$
$\mathrm{I} \cdot 5 \times 10^{9}$
$2 \times 10^{9}$
$2 \cdot 5 \times 10^{9}$
$8 \times 10^{9}$

Neuraminidase activity: $\mu \mathrm{g}$ NANA $/ \mathrm{ml}$ of cells

$$
\begin{array}{r}
240 \\
340 \\
400 \\
500 \\
640 \\
920 \\
2750
\end{array}
$$

few strains of $P$. haemolytica and P. pseudotuberculosis were tested for neuraminidase activity under the same conditions in order to find out if these Pasteurella strains also contained neuraminidase (Table I). Only three out of five $P$. haemolytica strains were positive for neuraminidase. No neuraminidase activity was found in $P$. pseudotuberculosis.

Effect of different sera on the synthesis of neuraminidase by Pasteurella multocida. Pasteurella multocida strain A-43 was found to produce the highest neuraminidase activity but also to require a rich medium for its cultivation. In order to evaluate the optimal growth conditions, we chose a medium consisting of brain heart infusion and $\mathrm{I} \%(\mathrm{w} / \mathrm{v})$ Casamino acids supplemented with 5 to $20 \%(\mathrm{v} / \mathrm{v})$ different sera. In these experiments a six- to eightfold higher neuraminidase activity per $\mathrm{ml}$ cell culture was measured when the medium contained $10 \%(\mathrm{v} / \mathrm{v})$ sheep serum, as compared to the serum-free control. This increase of neuraminidase activity in the presence of sheep serum was paralleled by the increase of cell number per $\mathrm{ml}$ of cell culture, measured as extinction. If other sera at $10 \%(\mathrm{v} / \mathrm{v})$ concentration were used, we received, compared to sheep serum, lower neuraminidase activities and cell numbers (Table 2). The relation of neuraminidase activity to cell number, however, was always constant. The enzyme present in $3 \times 10^{7}$ cells cleaved approximately $10 \mu \mathrm{g}$ NANA from I00 $\mu \mathrm{g}$ of bovine sialyllactose within $\mathrm{I} 5 \mathrm{~min}$ at $37^{\circ} \mathrm{C}$ in $0^{\circ} \mathrm{I} \mathrm{M}$-phosphate buffer, pH 6.0.

Induction of neuraminidase. Scharmann et al. (1970) described the inducibility of neuraminidase in Pasteurella multocida by $N$-acetyl-D-mannosamine, fetuin, $N$-acetylneuraminic acid, and sialyllactose. The highest neuraminidase activities per cell were obtained by using $\mathrm{N}$-acetyl-D-mannosamine for the induction of the enzyme. Fig. I shows differences in the time-dependent appearance of neuraminidase activity of $P$. multocida grown in basal medium (I), after addition of $N$-acetyl-D-mannosamine to the basal medium (2), and in a medium containing brain heart infusion, Casamino acids, and sheep serum (3). Neuraminidase activity of bacteria grown in basal medium reached its maximum already after 6 to Io h, independent of whether the medium contained $\mathrm{N}$-acetyl-D-mannosamine or not. In the presence of $N$-acetyl-D-mannosamine, neuraminidase activity was (with the same number of cells) ten times higher than in the absence of this substance. The maximum of neuraminidase activity and maximal cell numbers were reached at the same time. Due to the fact that after $22 \mathrm{~h}$ of incubation the cells started to flocculate, no activities occurring after that time were measured. 


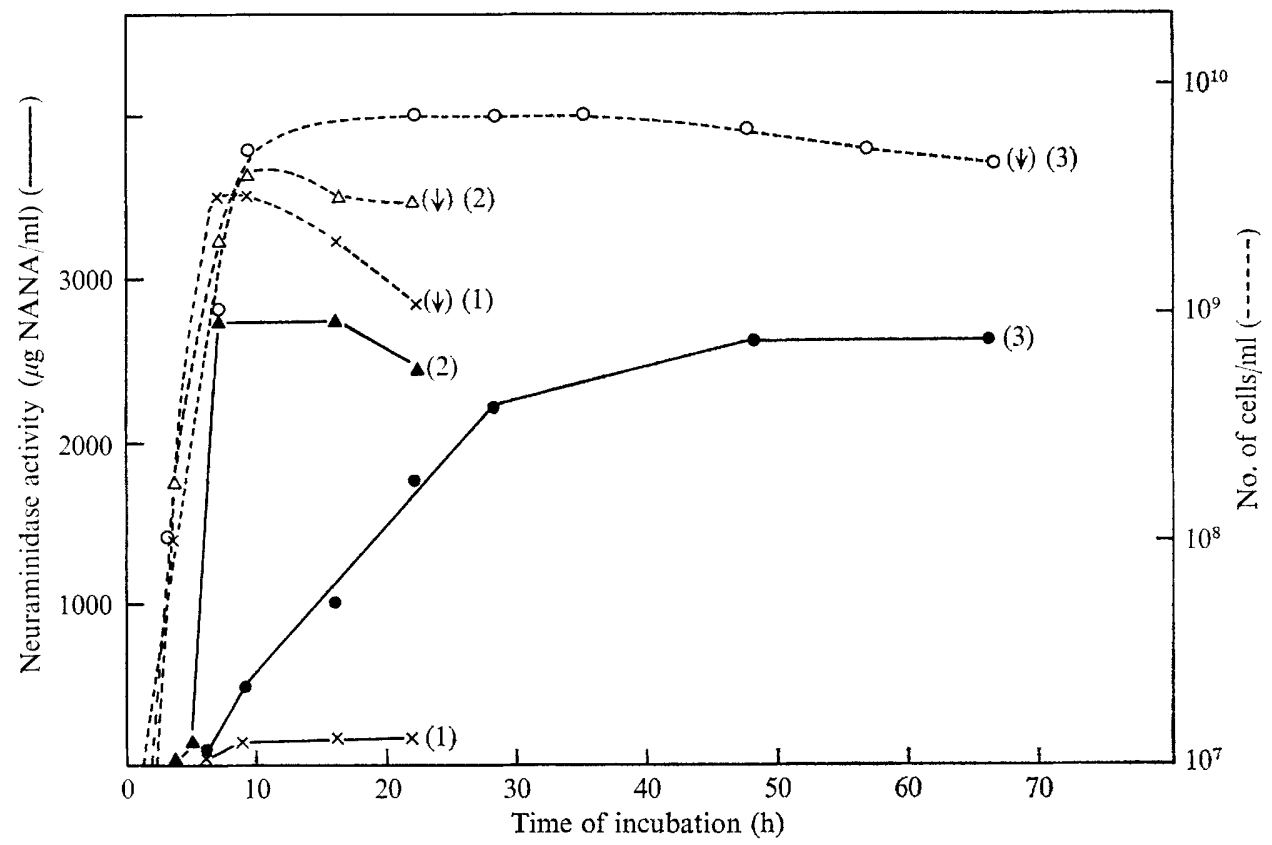

Fig. 1. Production of neuraminidase by Pasteurella multocida. I $\mathrm{ml}$ of a $6 \mathrm{~h}$ culture of $P$. multocida, strain A-43, containing $4 \times 10^{8}$ cells was inoculated into $100 \mathrm{ml}$ of three different culture media and incubated at $37^{\circ} \mathrm{C}$. Neuraminidase activity was expressed as $\mu \mathrm{g} N$-acetylneuraminic acid (NANA) liberated by $\mathrm{I} \mathrm{ml}$ of cell culture (see Table 2). The number of cells per ml of cell culture was determined by plating. (I) Basal medium: $\mathrm{I} \%$ yeast diffusate $+1 \%$ Casamino acids $+0.5 \% \mathrm{Na}_{2} \mathrm{HPO}_{4}$. ${ }_{12} \mathrm{H}_{2} \mathrm{O}$. (2) Basal medium (1) containing 2-mM $N$-acetyl-D-mannosamine. (3) Brain heart infusion $+\mathrm{I} \%$ Casamino acids $+10 \%$ sheep serum.

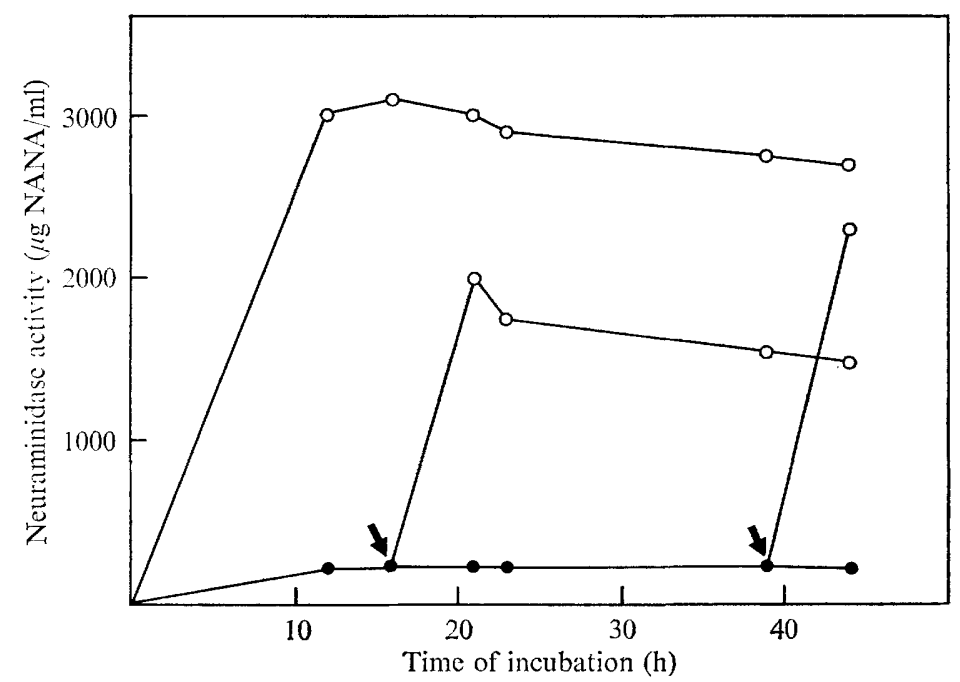

Fig. 2. Induction of neuraminidase in Pasteurella multocida. $N$-acetyl-D-mannosamine (2 mM) was present in a culture of $P$. multocida in basal medium (containing initially $4 \times 10^{8}$ cells in $100 \mathrm{ml}$ ) at the time of inoculation or after $\mathrm{I} 6$ and $39 \mathrm{~h}$ of incubation at $37^{\circ} \mathrm{C}$ (arrows). Neuraminidase activity was measured and expressed in $\mu \mathrm{g} N$-acetylneuraminic acid per $\mathrm{ml}$ of cell culture. $-\rightarrow$, Neuraminidase activity of $P$. multocida grown in basal medium; $\mathrm{O}-\mathrm{O}$, neuraminidase activity after addition of $N$-acetyl-D-mannosamine to the culture. 


\section{Table 3. Cell-bound and solubilized neuraminidase}

Pasteurella multocida, strain A-43, was grown for $66 \mathrm{~h}$ in an enriched medium to a density of about $8 \times 10^{9}$ cells $/ \mathrm{ml}$ and then separated from the culture filtrate and washed. The washed cells were ultrasonicated or extracted with $0.4 \mathrm{M}-\mathrm{NaCl}$. Neuraminidase activity was expressed in $\mu \mathrm{g}$ NANA per I $\mathrm{ml}$ of cell culture or the appropriate amount derived thereof. The protein content of the sample was determined with Folin-Ciocalteu's phenol reagent as described by Kabat \& Meyer (I964) using bovine serum albumin as standard.

$\begin{array}{lccc} & \begin{array}{c}\text { Neuraminidase } \\ \text { activity } \\ (\mu \mathrm{g} \text { NANA } / \mathrm{ml})\end{array} & \begin{array}{c}\text { Specific enzymatic } \\ \text { Pactivity } \\ (\mathrm{mg} / \mathrm{ml})\end{array} & \begin{array}{c}\mu \mathrm{g} \text { NANA released } \\ \text { Preparation }\end{array} \\ \text { Cell-free culture filtrate } & 240 & \mathbf{1 8 . 2} & \mathbf{m g} \text { protein } \\ \text { Washed cells } & 2625 & 0.6 & 4370 \\ \text { Supernatant of ultra- } & 1350 & 0.4 & 3380 \\ \text { sonicated cells } & 220 & 0.03 & 7350 \\ \text { NaCl extract } & & & \end{array}$

In cells grown in a rich medium consisting of brain heart infusion, Casamino acids and sheep serum, the maximal neuraminidase activity was observed after 50 to $70 \mathrm{~h}$; at a point when the cell density was already decreased. After approximately $72 \mathrm{~h}$ the cells began to clot and flocculate. The velocity of cell division in this medium was identical to that in basal medium.

A comparison of the highest level of neuraminidase activity per bacterium in different culture media showed that in basal medium $3 \times 10^{8}$ cells were necessary to produce that amount of neuraminidase which could cleave ro $\mu \mathrm{g} \mathrm{N}$-acetylneuraminic acid from $100 \mu \mathrm{g}$ bovine sialyllactose within $15 \mathrm{~min}$. In the presence of $N$-acetyl-D-mannosamine only $2 \times 10^{7}$ cells were needed for the same neuraminidase activity. In the medium containing sheep serum $3 \times 10^{7}$ cells were necessary.

The data in Fig. I show that neuraminidase activity induced by $N$-acetyl-D-mannosamine appeared during the logarithmic growth phase of the cells. Therefore, we investigated the influence of $\mathrm{N}$-acetyl-D-mannosamine on the induction of neuraminidase at different times after inoculation and also when cell flocculation was observed. As demonstrated in Fig. 2, the addition of $N$-acetyl-D-mannosamine always resulted in a considerable increase of neuraminidase activity, even if added $39 \mathrm{~h}$ after inoculation.

We also tried to induce this enzyme by addition of $N$-acetyl-D-mannosamine to those Pasteurella multocida strains which did not show neuraminidase activity. No neuraminidase activity could be detected in these cases.

Virulence. Pasteurella multocida strains showed great differences in their virulence in mice. Our experiments indicated also great differences in the neuraminidase activity of different strains. Therefore, we endeavoured to answer the question of a possible correlation existing between neuraminidase activity and virulence of $P$. multocida in mice. A comparison of bacterial virulence in mice with the measured neuraminidase activity of different $P$. multocida strains failed to result in a correlation of these parameters. The fact that neuraminidase is probably not a virulence factor of $P$. multocida is supported further by tests in which a neuraminidase-free strain (no. 34) showed the same virulence in mice as the neuraminidaserich strain A-43.

Solubilization of neuraminidase from Pasteurella multocida cells. For the characterization of Pasteurella multocida neuraminidase it was necessary to detach the enzyme from bacterial cells. Therefore, cells harvested after $66 \mathrm{~h}$ of inoculation were treated in different ways and 


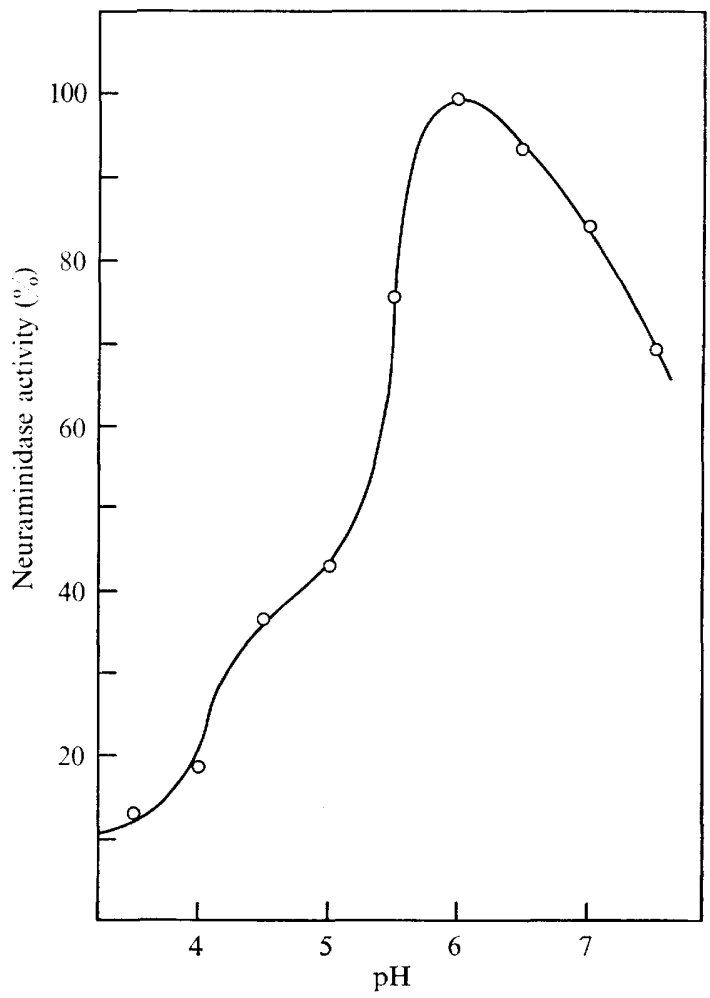

Fig. 3. pH-Optimum of the neuraminidase of Pasteurella multocida. Neuraminidase of $P$. multocida partially purified by the ammonium sulphate procedure was incubated at $37^{\circ} \mathrm{C}$ for 15 min with I $00 \mu \mathrm{g} 3^{\prime}$-sialyllactose in 0.1 M-acetate buffer $\left(\mathrm{pH}_{3} .5\right.$ to 5.5$)$ or in 0.1 M-phosphate buffer $(\mathrm{pH} 6.0$ to $7 \cdot 5$ ). Liberated $N$-acetylneuraminic acid was determined according to Aminoff's (I96I) procedure. Neuraminidase activity was expressed in per cent of the maximal value found at $\mathrm{pH} 6 \cdot 0$.

\section{Table 4. Degradation of $\mathrm{N}$-acetylneuraminic acid by Pasteurella multocida}

Pasteurella multocida, strain A-43, was grown for $66 \mathrm{~h}$ to a density of about $\mathrm{I} \times 10^{10} \mathrm{cells} / \mathrm{ml}$ and then centrifuged at $31000 \mathrm{~g}$ for $20 \mathrm{~min}$. The bacteria were washed three times with $0.1 \mathrm{M}$-phosphate buffer, $\mathrm{pH} 6.0$, and resuspended in this buffer to the original density. One part of the washed bacteria was ultrasonicated, another part was extracted with $0.4 \mathrm{M}-\mathrm{NaCl}$. A $0.2 \mathrm{ml}$ portion of the prepared sample was incubated with $100 \mu \mathrm{g} \mathrm{N}$-acetylneuraminic acid dissolved in $0.3 \mathrm{ml} \mathrm{of}$ $0.05 \mathrm{M}$-acetate buffer, $\mathrm{pH} 5.5$. After $15 \mathrm{~min}$ at $37^{\circ} \mathrm{C} \mathrm{N}$-acetylneuraminic acid still present in the sample was determined. The observed disappearance of $\mathrm{N}$-acetylneuraminic acid was expressed in per cent of the amount present at time zero in the sample.

\begin{tabular}{|c|c|c|c|c|}
\hline \multirow[b]{2}{*}{$\begin{array}{c}\text { Time } \\
\text { after } \\
\text { inoculation }\end{array}$} & \multicolumn{4}{|c|}{$\begin{array}{l}\text { NANA-degradation }(\%) \text { after incubation at } 37^{\circ} \mathrm{C} \\
\text { for } 15 \text { min with }\end{array}$} \\
\hline & $\begin{array}{c}\text { Cell-free } \\
\text { culture } \\
\text { medium } \\
(\%)\end{array}$ & $\begin{array}{c}\text { Washed } \\
\text { cells } \\
(\%)\end{array}$ & $\begin{array}{c}\text { Ultrasonicated } \\
\text { bacterial } \\
\text { supernatant } \\
(\%)\end{array}$ & $\begin{array}{c}\mathrm{NaCl} \\
\text { extract } \\
(\%)\end{array}$ \\
\hline 24 & $8 I$ & 37 & 45 & 0 \\
\hline $4^{8}$ & 60 & 27 & 27 & 0 \\
\hline 72 & 53 & 24 & I 5 & 2 \\
\hline
\end{tabular}




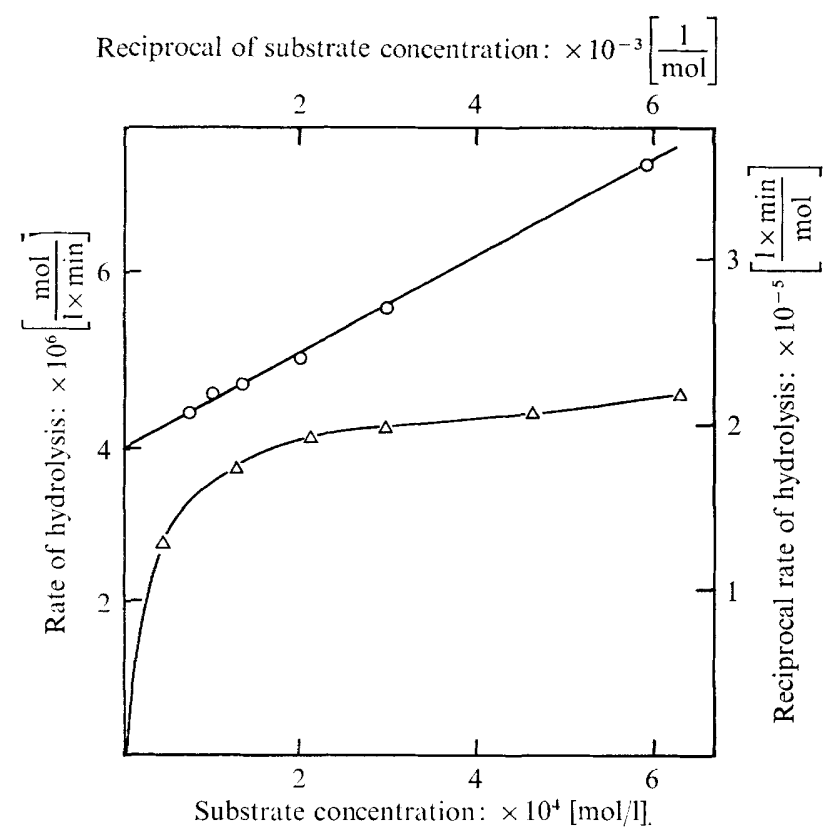

Fig. 4. Effect of substrate concentration upon the liberation of $N$-acetylneuraminic acid from $3^{\prime}$ sialyllactose by neuraminidase of Pasteurella multocida. Increasing concentrations of the substrate $3^{\prime}$-sialyllactose were incubated for I $5 \mathrm{~min}$ at $37^{\circ} \mathrm{C}$ in $0^{\circ} \mathrm{I} \mathrm{M}$-phosphate buffer, $\mathrm{pH} 6.0$, and the liberated $N$-acetylneuraminic acid was determined. The rate of hydrolysis of $3^{\prime}$-sialyllactose (left ordinate) was plotted against the substrate concentration (lower abscissa): $\triangle-\triangle$. The reciprocal values were calculated according to Lineweaver \& Burk (I934) and plotted (O- $\bigcirc$ ) on the right ordinate and upper abscissa as already described in a previous paper (Drzeniek et al. I966).

centrifuged at $31000 \mathrm{~g}$ for $20 \mathrm{~min}$. The neuraminidase activity of the supernatant was measured. After ultrasonication, up to $60 \%$ of the total neuraminidase was found in the supernatant. This amount could be increased by $10 \%$ by means of subsequent extraction with $0.4 \mathrm{M}-\mathrm{NaCl}$. $\mathrm{NaCl}$ extraction without ultrasonication showed that this method could release approximately $10 \%$ of the cell-bound neuraminidase.

Unfortunately, neuraminidase preparations obtained by ultrasonication precipitated readily when left standing at $4{ }^{\circ} \mathrm{C}$, and their specific activity was smaller than that of untreated cells (Table 3). They also contained the enzyme $\mathrm{N}$-acetylneuraminate pyruvatelyase (Table 4). Therefore, we used $\mathrm{NaCl}$ extraction for the preparation of solubilized neuraminidase. The $\mathrm{NaCl}$ extracts were mixed with solid ammonium sulphate at $4{ }^{\circ} \mathrm{C}$ ( $5 \mathrm{IO} \mathrm{g}\left(\mathrm{NH}_{4}\right)_{2} \mathrm{SO}_{4}$ to $\mathrm{I} 1$ of extract). The precipitate was centrifuged at $2200 \mathrm{~g}$ for $20 \mathrm{~min}$ at $4{ }^{\circ} \mathrm{C}$, suspended in Io $\mathrm{ml}$ of water, and dialysed against $\mathrm{H}_{2} \mathrm{O}$. The neuraminidase yield of the ammonium sulphate purification step was 60 to $80 \%$; the specific activity increased by a factor of 4 to Io in different preparations.

Thermal stability. Neuraminidase preparations partially purified by the ammonium sulphate procedure containing $0.33 \mathrm{mg}$ protein $/ \mathrm{ml}$ were incubated without substrate in O.I M-phosphate buffer, $\mathrm{pH} 6.0$, for $15 \mathrm{~min}$ to $24 \mathrm{~h}$ at $37^{\circ} \mathrm{C}$ and thereafter tested in the standard assay. No decrease of activity was noted up to $60 \mathrm{~min}$. Twenty-four h later the neuraminidase activity was still $93 \%$.

pH-Optimum. Fig. 3 shows the liberation of $N$-acetylneuraminic acid from 3 -sialyllactose at different $\mathrm{pH}$ values. The maximum of neuraminidase activity was measured at $\mathrm{pH} 6 \cdot 0$. 


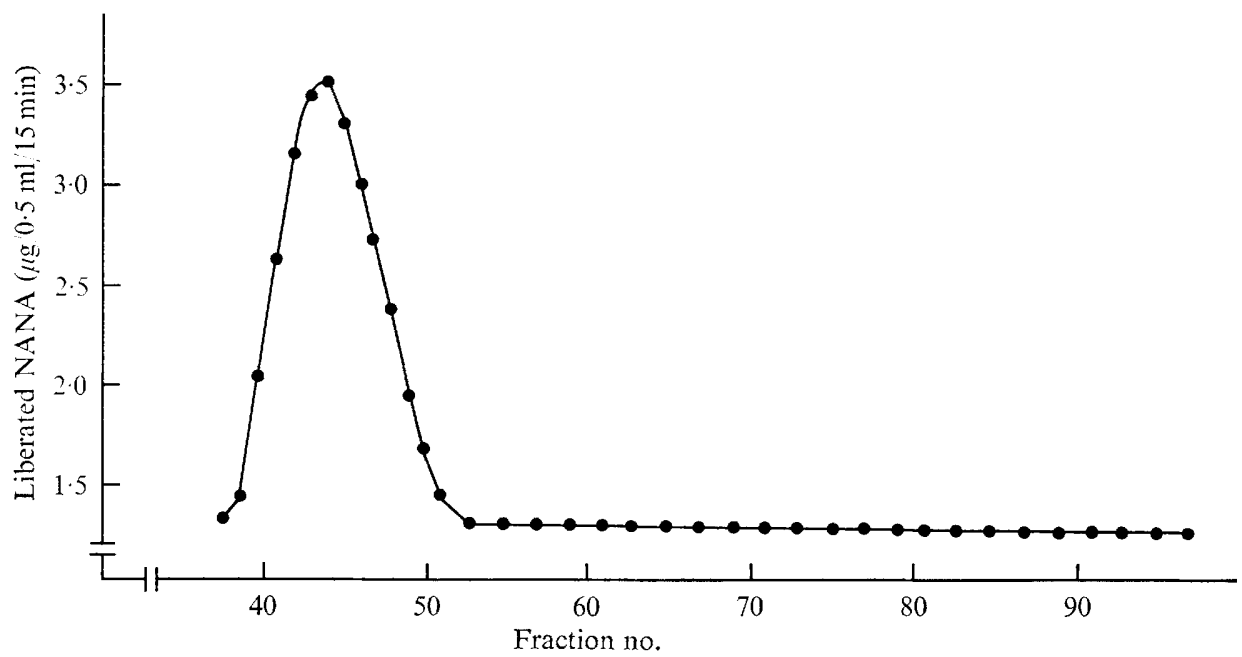

Fig. 5. Gel filtration of neuraminidase of Pasteurella multocida on Sephadex G I 50. Neuraminidase preparations obtained by extraction of $P$. multocida with $0 \cdot 4 \mathrm{M}-\mathrm{NaCl}$ were subjected to gel filtration on a Sephadex G 150 column $\left(\mathrm{I} \cdot 6 \times \mathrm{I}_{23} \mathrm{~cm}\right)$. For the elution, a $0.05 \mathrm{M}$-phosphate buffer, $\mathrm{pH} 6.0$, containing $0.1 \mathrm{M}-\mathrm{KCl}$ was used. Fractions $(2 \mathrm{ml})$ were collected. Ordinate: neuraminidase activity, expressed in $\mu \mathrm{g} / 0.5 \mathrm{ml} / 15 \mathrm{~min}$ of $\mathrm{N}$-acetylneuraminic acid (NANA), liberated from fetuin as substrate by properly diluted fractions (see Methods). Abscissa: fraction number of the eluate from the Sephadex column.

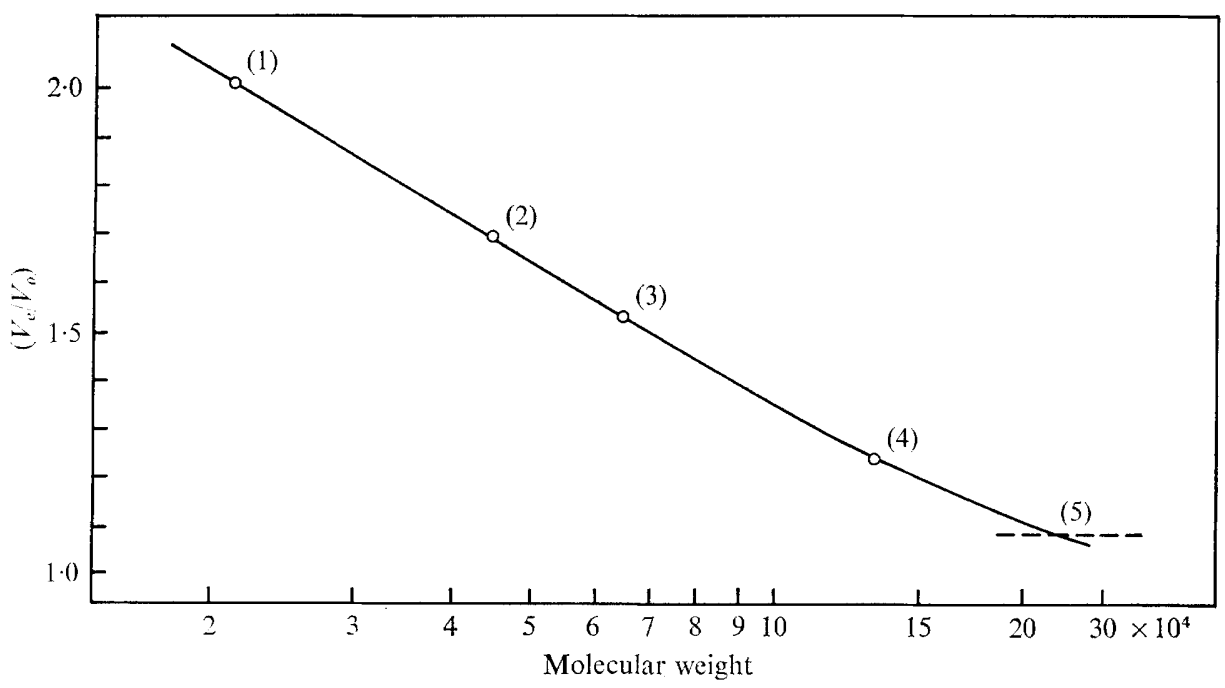

Fig. 6. Determination of the molecular weight of Pasteurella multocida neuraminidase. The elution volume of neuraminidase (5) derived from Fig. 5 and of 4 molecular weight standards ( $I$ to 4 ) on the same Sephadex G I 50 column was used for the calculation of the molecular weight of $P$. multocida neuraminidase. The procedure was described in detail elsewhere (Balke \& Drzeniek, I 969). $V_{o}=$ void volume; $V_{e}=$ elution volume. Molecular weight standards: (I) trypsin inhibitor; (2) ovalbumin; (3) bovine serum albumin (monomer); (4) bovine serum albumin (dimer). 


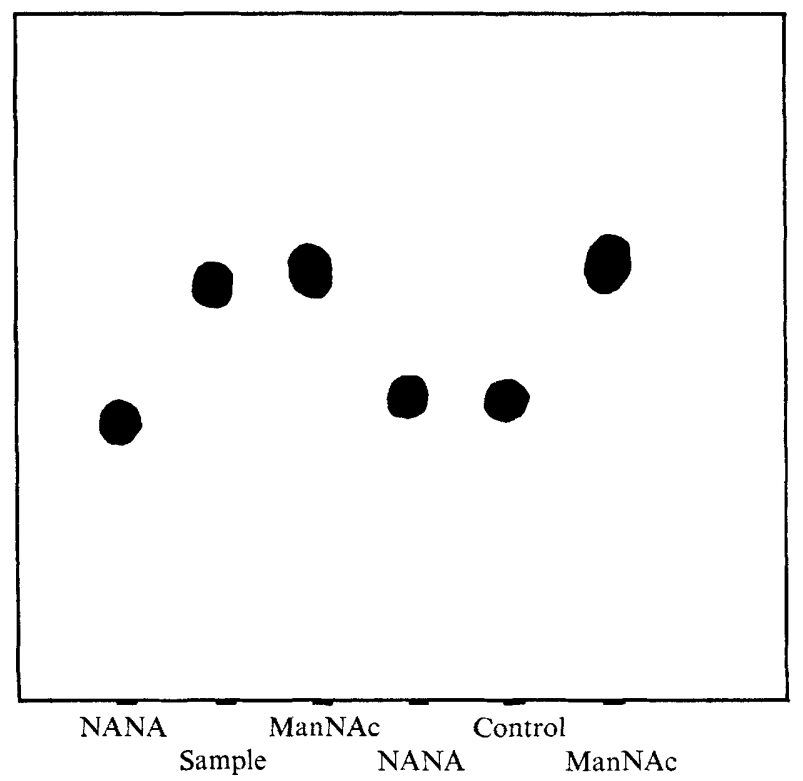

Fig. 7. Conversion of $N$-acetylneuraminic acid to $N$-acetyl-D-mannosamine by a cell-free extract of Pasteurella multocida. Bacteria $\left(4 \times \mathrm{IO}^{10}\right)$ were suspended in $4 \mathrm{ml}$ of an $\mathrm{O} \cdot \mathrm{I} \mathrm{M}$-phosphate buffer, $\mathrm{pH} 6.0$, ultrasonicated and centrifuged for $20 \mathrm{~min}$ at $3 \mathrm{I} 000 \mathrm{~g}$. A $0.2 \mathrm{ml}$ sample of the supernatant was incubated for $\mathrm{I} 8 \mathrm{~h}$ at $37^{\circ} \mathrm{C}$ with $\mathrm{I} \mathrm{mg}$ of $\mathrm{N}$-acetylneuraminic acid dissolved in $0.3 \mathrm{ml}$ of $0.05 \mathrm{M}$-acetate buffer, $\mathrm{pH}_{5.5}(=$ sample) and subsequently subjected to descending paper chromatography in the following system: paper, Schleicher-Schüll $2043 \mathrm{~b}$; solvent, butyl acetate/acetic acid/water $=3 / 2 / 1$; time, $16 \mathrm{~h}$. The paper chromatogram was cut into two pieces. $N$-acetylneuraminic acid (NANA) was visualized by the direct Ehrlich reaction as described by Gottschalk (I960). $N$-acetyl-D-mannosamine (ManNAc) was detected by the Morgan-Elson reaction as given by Horton (1969). The control was treated in the same way as the sample, but the $P$. multocida extract was omitted.

Dependence of NANA liberation on substrate concentration. Fig. 4 shows the liberation of $\mathrm{N}$-acetylneuraminic acid from 3 '-sialyllactose in dependence of the substrate concentration. Evaluation of these tests according to Lineweaver \& Burk (1934) results in a Michaelis constant of $K_{m}=2 \times 10^{-4} \mathrm{M}$.

Test for determination of molecular weight of Pasteurella multocida neuraminidase. To determine the molecular weight of the neuraminidase isolated by $\mathrm{NaCl}$ extraction from $P$. multocida, a gel filtration of the preparations was performed on Sephadex G I50 as described earlier (Balke \& Drzeniek, 1969). These experiments show (Fig. 5) that the neuraminidase of $P$. multocida moves as a single band, no lower molecular weight material being detected. The elution volume $\left(V_{e}\right)$ of neuraminidase was $43.8 \mathrm{ml}$; the void volume $\left(V_{o}\right)$ was determined at $40.1 \mathrm{ml}$ of the eluate. From these values and molecular weight standards the molecular weight can be calculated by extrapolation to be about 250000 daltons (Fig. 6).

$N$-acetylneuraminate pyruvate-lyase activity in Pasteurella multocida. Incubation of $P$. multocida in a medium containing $2 \mathrm{mM}$ of $\mathrm{N}$-acetylneuraminic acid for $7 \mathrm{~h}$ at $\mathrm{pH} 6.0$ and $37^{\circ} \mathrm{C}$ showed less than $0.02 \mathrm{~mm}$ of the substance to be present after this time in the test system. It was thought that the disappearance of $N$-acetylneuraminic acid was caused by the enzyme $N$-acetylneuraminate pyruvate-lyase. In order to show unequivocally that the described decrease of $N$-acetylneuraminic acid was caused by $N$-acetylneuraminate pyruvatelyase, the appearance of $N$-acetyl-D-mannosamine was shown by paper chromatography when the supernatant of ultrasonicated bacteria was used as source of the enzyme (Fig. 7). 
From Table 4 it is obvious that higher activities of $N$-acetylneuraminate pyruvate-lyase are present in the cell-free supernatant than in washed bacteria, independent of the time of growth of the bacteria. Ultrasonication of bacteria (as used for the liberation of neuraminidase) also liberated $\mathrm{N}$-acetylneuraminate pyruvate-lyase activity into the cell-free supernatant. However, the treatment of bacteria with $0.4 \mathrm{M}-\mathrm{NaCl}$ solutions did not have a releasing effect on $N$-acetylneuraminate pyruvate-lyase.

\section{DISCUSSION}

As in the case of Corynebacterium diphtheriae (Moriyama \& Barksdale, 1967) and Klebsiella aerogenes (Pardoe, 1970), the neuraminidase of Pasteurella multocida is bound to the bacterial cell. It can be liberated from $P$. multocida by ultrasonication or $\mathrm{NaCl}$ extraction. After liberation from the bacterial cell the enzyme displays a high tendency to aggregate at neutral $\mathrm{pH}$ values. The molecular weight of $P$. multocida neuraminidase found by means of gel chromatography is in the range of 250000 . This value is much higher than all molecular weights of bacterial neuraminidases reported up till now which were found to be in the range of 60000 to 90000 (Drzeniek, I972). Only the neuraminidase of Streptococcus viridans shows approximately the same molecular weight as $P$. multocida neuraminidase (E. Balke, W. Scharmann \& R. Drzeniek, in preparation). The reason for this high molecular weight of some bacterial neuraminidases is unknown.

The solubilized enzyme has the same $\mathrm{pH}$-optimum and kinetic characteristics as the cellbound enzyme. The determined $\mathrm{pH}$-optimum of $\mathrm{pH} 6.0$ is in the range found for other bacterial neuraminidases (Gottschalk \& Drzeniek, 1972). The Michaelis constant with $K_{m}=2 \times 10^{-4} \mathrm{M}$ for $\mathrm{N}$-acetylneuraminosyl $(\alpha, 2 \rightarrow 3)$-D-lactose as substrate is the lowest reported.

Pasteurella multocida neuraminidase is an inducible enzyme. The highest enzyme activity was obtained by the addition of $N$-acetyl-D-mannosamine to the growth medium. This finding is in agreement with earlier reports on the inducibility of neuraminidase of different bacteria. Thus, neuraminidase of Vibrio cholerae (Ada \& French, I959; French \& Ada, I959), Diplococcus pneumoniae (Kelly, Greiff \& Farmer, 1966), and Klebsiella aerogenes (Pardoe, 1970) was induced by substances containing sialic acid. Vibrio cholerae neuraminidase was induced by $N$-acetyl-D-mannosamine (Ada \& French, 1959).

Our recent experiments reveal that prolonged incubation of Pasteurella multocida in a medium containing blood sera of various animals results in a delayed increase of neuraminidase activity when compared to bacteria grown in the presence of $N$-acetyl-D-mannosamine. $N$-acetyl-D-mannosamine acts very rapidly, the maximum of neuraminidase activity being reached after $6 \mathrm{~h}$, as compared to 50 to $60 \mathrm{~h}$ with a medium containing sheep serum. This delayed appearance of neuraminidase is not due to differences in the amount of bacteria since the inoculum and the bacterial growth curves were identical in these experiments. Furthermore, $N$-acetyl-D-mannosamine promptly induces neuraminidase activity, not only during the logarithmic growth of the bacteria, but also in a later period. Therefore, it has to be assumed that the delayed inducing effect of animal sera on neuraminidase activity in $P$. multocida is caused by a slow release of the low molecular weight inducer.

We reported earlier that $N$-acetylneuraminic acid also induces neuraminidase activity, though to a lower degree when compared on a molecular basis with $N$-acetyl-D-mannosamine (Scharmann et al. 1970). The fast disappearance of $N$-acetylneuraminic acid observed in cultures of Pasteurella multocida and the presence of $N$-acetylneuraminate pyruvate-lyase in these cells suggest that $N$-acetyl-D-mannosamine is the neuraminidase inducer. The immediate action of $N$-acetyl-D-mannosamine at all stages of bacterial growth and its higher 
inducing effect are in agreement with this statement. The specific action of $N$-acetyl-D-mannosamine is also supported by the lack of neuraminidase induction by $N$-acetyl-D-glucosamine.

We wish to thank Miss M. Orlich, Mrs H. Perkitny, and Miss B. Schulz for skilful technical assistance. This investigation was supported by the Deutsche Forschungsgemeinschaft.

\section{REFERENCES}

AdA, G. L. \& FRENCH, E. L. (1959). Stimulation of the production of neuraminidase in Vibrio cholerae cultures by $N$-acetyl-mannosamine. Journal of General Microbiology 21, 56I-568.

AMINOFF, D. (196I). Methods for the quantitative estimation of $N$-acetylneuraminic acid and their application to hydrolysates of sialomucoids. Biochemical Journal 81, 384-392.

BALKE, E. \& DrZENIEK, R. (1969). Untersuchungen über die Clostridium perfringens-Neuraminidase. Zeitschrift für Naturforschung $\mathbf{2 4} b, 599-603$.

CARTeR, G. R. (1967). Pasteurellosis: Pasteurella multocida and Pasteurella hemolytica. In Advances in Veterinary Science: Clinical Biochemistry of Domestic Animals, vol. II, pp. 321-379. Edited by C. A. Brandly \& C. E. Cornelius, New York: Academic Press.

Collins, C. H. \& Lyne, P. M. (1970). Microbiological Methods, p. 177. London: Butterworths and Baltimore: University Park Press.

DRZENIEK, R. (1970). Wechselwirkungen zwischen Myxoviren und Zelloberflächen. Zeitschrift für Medizinische Microbiologie und Immunologie 155, 315-35I ; 156, I-38.

DRZENIEK, R. (1972). Viral and bacterial neuraminidases. In Current Topics in Microbiology and Immunology, vol. 59. Berlin, Heidelberg, New York: Springer-Verlag (in the Press).

Drzeniek, R., Seto, J. T. \& Rott, R. (1966). Characterization of neuraminidases from myxoviruses. Biochimica et biophysica acta 128, 547-558.

French, E. L. \& ADA, G. L. (1959). Stimulation of the production of neuraminidase in Vibrio cholerae cultures by $N$-acetyl-neuraminic acid and sialyl-lactose. Journal of General Microbiology 2r, 550-560.

Gotrschalk, A. (1960). The Chemistry and Biology of Sialic Acids and Related Substances. Cambridge University Press.

Gottschalk, A. \& Drzeniek, R. (1972). Neuraminidase as a tool in structural analysis. In Glycoproteins, Their Composition, Structure and Function, 2nd edn, pp. 38I-402. Edited by A. Gottschalk. Amsterdam: Elsevier Publishing Co.

Horton, D. (1969). Monosaccharide amino sugars. In The Amino Sugars, vol. IA, pp. 3-2II. Edited by W. Jeanloz. New York and London: Academic Press.

Kabat, E. A. \& Meyer, M. M. (1964). Experimental Immunochemistry, 2nd edn., p. 557. Springfield, Illinois: Charles Thomas.

Kelly, R. T., Greiff, D. \& Farmer, S. (1966). Neuraminidase activity in Diplococcus pneumoniae. Journal of Bacteriology 9I, 60I-603.

LAURELL, A. B. (1959). Neuraminidase-like factors in cultures of pneumococci, $\alpha$-streptococci and Pasteurella pseudotuberculosis. Acta pathologica et microbiologica scandinavica 47, 182-190.

LiNEWEAVER, H. \& BURK, D. J. (1934). The determination of enzyme dissociation constants. Journal of the American Chemical Society 56, 658.

Moriyama, T. \& BARKSDALE, L. (1967). Neuraminidase of Corynebacterium diphtheriae. Journal of Bacterio$\log y$ 94, $1565-158 \mathrm{I}$.

MüLLER, H. E. (197I). Untersuchungen in vitro über die Neuraminidase der Pasteurella multocida. Zentralblatt für Bakteriologie, Parasitenkunde, Infektionskrankheiten und Hygiene (Abteilung I. Originale) A 217, 326-344.

PARDOE, G. I. (1970). The inducible neuraminidase ( $N$-acyl-neuraminyl hydrolase EC 3.2 . I . I 8) of Klebsiella aerogenes NCIB 9479. Pathologia et microbiologiya 35, 36I-376.

ScharmanN, W. \& Blobel, H. (1968). Serologische Untersuchungen von Staphylokokken-Nucleasen. Zeitschrift für Naturforschung $\mathbf{2 3} b, \mathrm{I} 230-\mathbf{1 2 3 5}$.

SCHARMANN, W., BRÜCKLER, J. \& Blobel, H. (1971). Wirkung bakterieller Neuraminidasen auf Transferrin vom Menschen, Rind und Kaninchen. Biochimica et biophysica acta 229, I36-142.

Scharmann, W., Drzeniek, R. \& Blobel, H. (1970). Neuraminidase of Pasteurella multocida. Infection and Immunity I, 319-320.

Tsolov, V. \& KaradzHov, Y. (1969). Neuraminidase activity of Pasteurella multocida. Doklody. Bulgaraska akademiya na naukite 22, 571-573. (Chemical Abstracts (1969) 71, 57834.) 